九州大学学術情報リポジトリ

Kyushu University Institutional Repository

Effectiveness of Environmental Restoration Induced by Various Trials for Preventing Desertification in Horqin Arid Land, China : Construction of Pilot Villages Based on Economical and Ecological Sustainability

Hao, Aimin

Graduate School of Bioresource and Bioenvironmental Sciences, Kyushu Unviersity

Yuge, Kozue

Faculty of Agriculture, Kyushu Unviersity

Nakano, Yoshisuke

Faculty of Agriculture, Kyushu Unviersity

Haraguchi, Tomokazu

Graduate School of Bioresource and Bioenvironmental Sciences, Kyushu Unviersity

他

https://doi.org/10.5109/4690

出版情報: 九州大学大学院農学研究院紀要. 50 (2)，pp.821-828，2005-10-01. Faculty of Agriculture, Kyushu University

バージョン：

権利関係 : 


\title{
Effectiveness of Environmental Restoration Induced by Various Trials for Preventing Desertification in Horqin Arid Land, China - Construction of Pilot Villages Based on Economical and Ecological Sustainability (Part 3) -
}

\author{
Aimin $\mathrm{HAO}^{1 *}$, Kozue YUGE, Yoshisuke NAKANO, \\ Tomokazu HARAGUCHI ${ }^{2}$ and Atsushi MARUI ${ }^{3}$
}

\author{
Laboratory of Irrigation and Water Utilization, Division of Regional Environment Science, \\ Department of Bioproduction Environmental Sciences, Faculty of Agriculture, \\ Kyushu University, Fukuoka 812-8581, Japan \\ (Received June 29, 2005 and accepted July 26, 2005)
}

\begin{abstract}
The basic idea for constructing the new agricultural system in the pilot village is to establish the economic sustainability with keeping the diversified agriculture. Farmers grow main products such as cereal crops, woods, fruits, vegetables and livestock. All the residues are used for producing compost and methane gas by the individual farmers with recycling system. Newly stabilized sand dune is not only effective for preventing sand drift but also effective for producing notorious grass for livestock. With producing grasses repeatedly, the soil physical and chemical properties are expected to be improved steadily. Wind shelter forests are effective for protecting agricultural area from strong wind and sand attack. Moreover these are effective for supplying woods and fuels, and litters are used for soil improvement. The long span land rental system is effective to improve the sustainable development of agriculture at the desert area in Naiman.
\end{abstract}

\section{INTRODUCTION}

Horqin arid land about $51,750 \mathrm{~km}^{2}$ was famous for the mixed zone of agriculture and livestock-raising district with some spreading deserts in Northern China. The development of this area has begun in 1950, thereafter, rapid increase of population has brought about the over grazing and over disafforestation. Since then these area has been suffering strong tendency of desertification. One of the main reasons of this desertification was the destruction of natural balance by the artificial activities. Another reason might be the global climate changes prevailing all over the earth. To overcome these sever situation in this arid area, it is expected to establish restoration project to stabilize the sand drift based on the ecological and economical sustainability (Jiang et al., 2002; Zhang, 1996).

From around 80', many pilot farmlands have been established. The final goal of this

\footnotetext{
1 Laboratory of Irrigation and Water Utilization, Division of Regional Environment Science, Department of Bioproduction Environmental Sciences, Graduate School of Bioresource and Bioenvironmental Sciences, Kyushu University

2 Laboratory of Bioproduction and Environment Information Sciences, Division of Bioproduction and Environment Information Sciences, Department of Bioproduction Environment Science, Faculty of Agriculture, Kyushu University

${ }^{3}$ Regional Environment System Engineering, Kyushu-Kyoritsu University

* Corresponding author (E-mail: aimin@bpes.kyushu-u.ac.jp)
} 
project is to construct agricultural area surrounded by the wind shelter forest bands, to grow out of the traditional mono-livestock to livestock combined with agriculture productivities, especially at three districts at Northern parts of China.

This pilot village project is expected to stop the enlargement of desert area. To attain the ecological and economical sustainability for agriculture, intrinsic geophysical conditions should be taken into account in this area. It is requested theoretical background to support the advancing project (Zhang et al., 1996; Guo et al., 2002).

The objective of this study is to establish the theory to improve the sustainable development of agriculture in Naiman. Questionnaire survey was conducted to the farmers for confirming the effectiveness of the project supported by the government.

\section{NATURAL CONDITIONS OF STUDY AREA}

Horqin arid land spreads west to east about $400 \mathrm{~km}$. About $75 \%$ of the Horqin arid land is classified as grassland. The altitude ranges from $631.9 \mathrm{~m}$ to $178.5 \mathrm{~m}$ with the stepwise slope declining to the Southeast. The differences of height between hilltop and bottom are about 5 to $10 \mathrm{~m}$. The basins of hill are sometimes enriched with groundwater. Historically, the first settlement was begun at those low lands between the hills.

The remaining $25 \%$ of this area is composed of sandy desert. The desert is classified as fixed, semi-fixed and shifting sand dunes with the ratios $36.5 \%, 46 \%$ and $17.5 \%$, respectively. Some of the fixed sand dune areas where groundwater resources exist are used for agricultural production. Those agricultural fields are distributed at low land area between the hills. The percentages of those agricultural fields in the fixed sand dune area are about $7.5 \%$ and residual part of the fixed sand dune are covered with grasses and bushes. Although those agricultural fields are fixed temporally, they are always suffering from the desertification. Semi-fixed sand dunes are covered with sparse weeds. Shifting sand dune areas were brought by the over grazing and disafforestation. These three types of deserts are always suffering from strong wind erosion, though some areas are semi-stabilized with grasses or bushes (Hou, 2004).

The climate of Horqin arid land can be characterized as, long sunshine duration, large temperature differences and scarce amount of precipitation. Except for the shortage of water, these areas have advantages of plentiful natural energy. If the problem of water shortage is resolved with introducing irrigation channels from river, economical standpoint of farmers will change for the better with growing orchard and crops suitable for the dry air condition.

\section{COMPOSITION OF PILOT VILLAGES}

In the pilot village, some families make a farmer's group for reclamation. The basic substances for the settlement are water, grass, food, forest and economical supporting system. The area is composed of Crop field-Orchard-Forest bands for wood production and for straw nets windbreak. The pilot villages constructed by the government are normally composed of $50 \%$ of straw-net area, $20 \%$ of wind shelter forest bands area, $10 \%$ of orchard area and $20 \%$ of crop field area. The schematic view of a pilot village is expressed as shown in Fig. 1 (Jiang et al., 2002). 


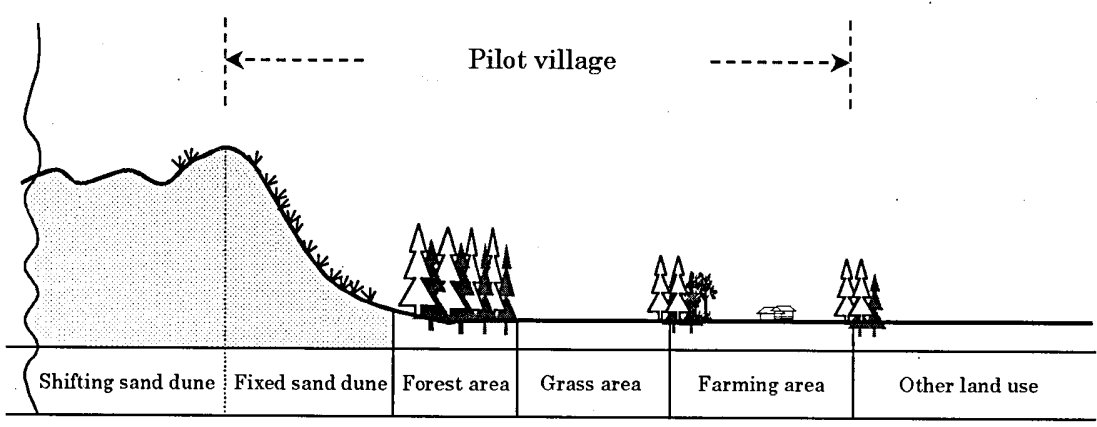

Fig. 1. Schematic view of a pilot village.

\section{Farming area}

The area of crop field in each farmers range from 0.3 ha to 2.0 ha depending on the numbers of the workers and financials in the family. As water is prerequisite for the residence, the places with high groundwater level were preferably selected.

Farmer's individual houses are placed in the center of the managing farmland. Typical home is composed of main house with some space for garden, toilet, cattle shed for caws and sheep, a silo for feed grass. Each family has well, electricity, farm road, crop field and grass field as shown in Fig. 2. Farmers grow crops for self-sufficient and marketing crops for earn monies. Most popular grass species are, Astragalus adsurgens, Medicago sativa and Clinelymus dahuricus, which are perennial, plants suitable for the climate in this area.

\section{Orchard area}

Orchard is placed outside of crop fields, and marketing fruits such as apple, pear, plum, Armeniaca sibirica (apricot) are grown. Inside of orchards, medical crops and various kinds of vegetables are grown. In some cases, few cattle are grown by planting nourishing grass.

\section{Grass area}

Species of grasses for cattle are Astragalus adsurgens, Caragana microphylla, Artemisia halodendron and Trigonella korshinskyi. The main livestock are cows, horses, sheep, pigs, donkeys, ducks and chickens.

\section{Wind shelter forest area}

The wind shelter forest areas are placed doubly outside of the main field facing to desert. The area of which is normally one to four times larger than the main field and has a most important role to prevent sand attack from sand dune area.

Outer forest is arranged with grid or circular shapes with densely populated band of 5 to 10 pieces of tree rows. In the centre of each row have toll trees such as Populus simonii (populous), Salix matsudana (willow), Pinus sylvestris var. (pain) and so on. 


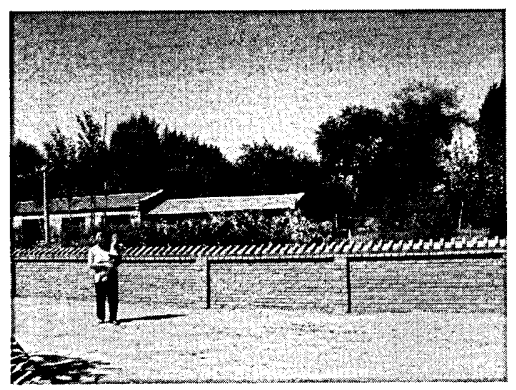

Dwelling place

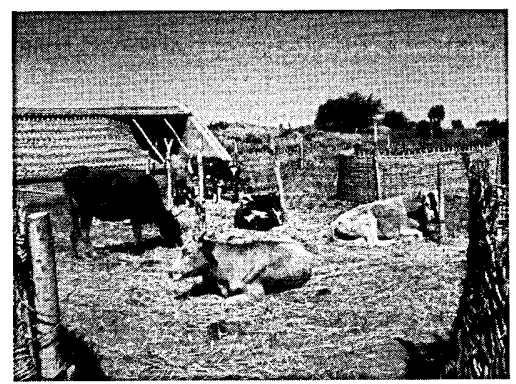

Cattle house

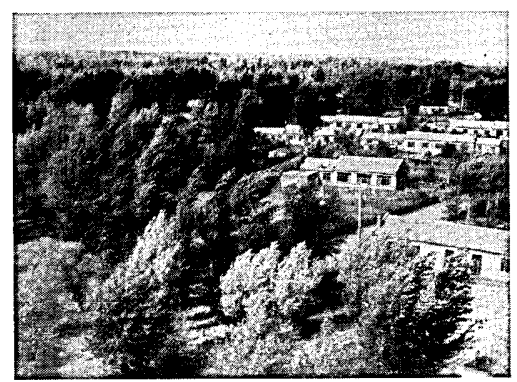

Residential area

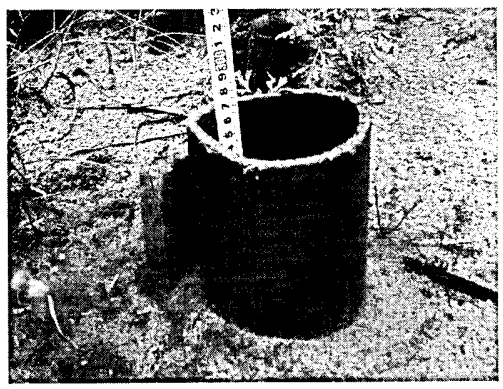

Irrigation Well (Depth about 3m)

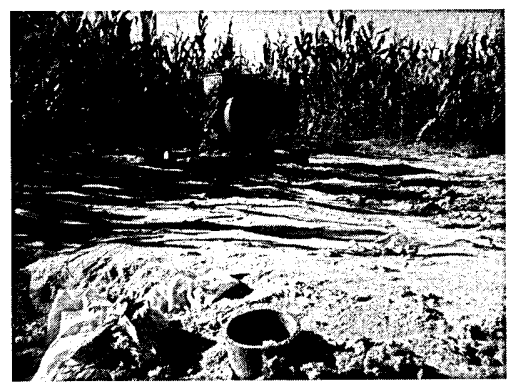

Irrigation pump

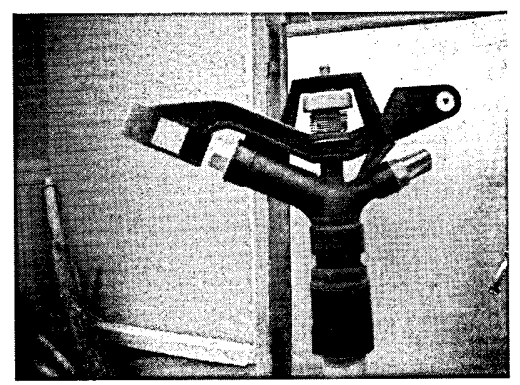

Irrigation sprinkler

Fig. 2. Pilot village.

Both side of toll trees, bushes such as Hippophae rhamnoides, Amorphy fruticosa, Lespedeza bicolor, P. tabulaeformis Carr are planted.

For inner wind shelter trees, Populous simonii (populous), Salix gordejevii (yellow willow) have been transplanted. Inside of the forest, intercrops or grasses are grown with rotation to keep away from damages of repeated cultivation. 


\section{Straw net area}

At the edge of sand dune area, straw nets with mesh size $1 \mathrm{~m}$ are placed width about $100 \mathrm{~m}$ to $300 \mathrm{~m}$, within two years before constructing the pilot village. The area ranges about 6 to 15 ha depending on the topographic conditions. Inside of the straw nets, Caragana microphylla, Astragalus adsurgens, Agriophyllum arenarium are transplanted.

\section{ECOLOGICAL AND ECONOMICAL SUSTAINABILITY OF PILOT VILLAGES}

The basic idea for constructing the new agricultural system is establishing the ecological and economical sustainability with keeping the diversified agriculture. Farmers grow main products such as cereal crops, woods, fruits, vegetables and livestock, at the same time they produce materials such as compost and methane gas. All the residues are used by the individual farmers with recycling system.

Newly stabilized sand dune is not only effective for preventing sand drift but also effective for producing notorious grass for livestock. With producing grasses repeatedly, the soil physical and chemical properties are expected to be improved steadily. Wind shelter forests are effective for protecting agricultural area from strong wind and sand attack but also effective for supplying woods and fuels. Moreover litters are used for soil improvement and grass is grown in the space inside the forests.

During 1995 to 2000 financial supports were conducted by the government in the Northern districts under the project for combating the desertification and agricultural development. For activating the local economy, some sandy lands were put up to auction for rental contract about 10 to 30 years. The policies to introduce long span private enterprise were promoted positively. Private ownership was outstandingly effective to improve the daily life conditions of peoples in those rural areas. The farmers have duty to pay the government big money when they break the contract. Normally each family has their own farming area about 13 ha in average. When the farmers raise caws, it is recommended to keep 30, and in the case of pigs or sheep, recommended numbers are 50 and 100, respectively. Farmers are requested to feed livestock with self-support food. Another duty for the farmers are to keep wind shelter forest in good condition. The target percentages of safely grown trees after planting is recommended as $90 \%$. The wind shelter forests, protecting the crop fields and roads are maintained and managed by the provincial government. The outer edge of the forest area, front line forests areas are placed with sand protecting fences and straw nets. These are controlled by the government.

During 1995 to 2000, totally 140 pilot villages with 547 families were constructed by this project in Naiman. Fig. 3 shows the places in which pilot villages were constructed. The numbers of villages and families are shown in the figure. The total area 13,869 ha is composed of crop fields, 2,412 ha, grass field, 1,206 ha, medical crop field, 402 ha, orchard, 1,206 ha, forest, 5,561 ha, pasture, 2,278 ha and others, 804 ha, respectively. Each village has about 100 ha area with about 4 families.

The results of statistical survey on economy in villages showed as follows: (1) Average area of managing land of individual farmers was 0.6 ha. (2) Average initial expenditure to start residence was 35,000 yen (Japanese yen). In which, 20,000 yen was 


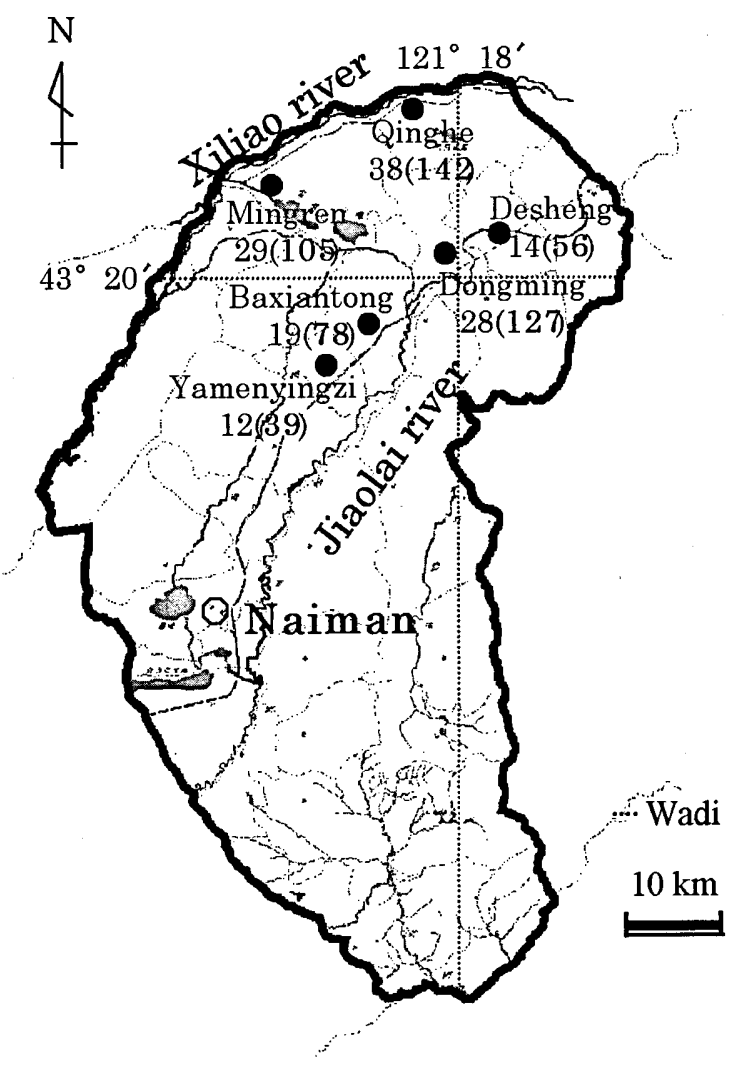

Fig. 3. Pilot villages in Naiman.

used for irrigation facilities such as well digging, sprinkler nozzles, pipes and pumps and 15,000 yen/ha was used for land rental cost. (3) Average annual income was 29,000 yen. This is 1.8 times better than that of 10 years ago. With introducing private ownership of lands had effects to increase income.

Questionnaire survey was conducted in Sept. 2003 at to the farmers for confirming the effectiveness of the project supported by the government for the development of the sustainable agriculture. Totally 12 families were selected on this investigation and asked them on occupation, race, age, type of operation, finance conditions (expenditure and income), labor Day, composition of families and land use.

Table 1. shows that composition of each races. Ratio of Chinese is almost the same as Mongolian. Average members of family are 4.2. Average age of farmers was 51.3. It was clarified that $90 \%$ of laborers work over 200 days. The average area crop field per family was $2.8 \mathrm{ha}$, and grass field was $17.5 \mathrm{ha}$. Income and expenditure per family were 109,000 yen and 82,000 yen in average, respectively. 
Table 1. Economical condition of farm families in pilot village (2003).

\begin{tabular}{|c|c|c|c|c|c|c|c|}
\hline \multirow[b]{2}{*}{ Items } & \multicolumn{2}{|c|}{ Finance } & \multirow{2}{*}{$\begin{array}{l}\text { Labor days } \\
\text { d/y/person }\end{array}$} & \multicolumn{2}{|c|}{ Compostion } & \multicolumn{2}{|c|}{ Farm area } \\
\hline & $\begin{array}{l}\text { Expenditure } \\
\text { (Jp. yen) }\end{array}$ & $\begin{array}{l}\text { Income } \\
\text { (Jp. yen) }\end{array}$ & & Total & Farmers & $\begin{array}{l}\text { Crop } \\
\text { (ha) }\end{array}$ & $\begin{array}{c}\text { Grass } \\
\text { (ha) }\end{array}$ \\
\hline Min & 14,000 & 17,000 & 180 & 2 & 1 & 0.5 & 1.3 \\
\hline $\operatorname{Max}$ & 164,000 & 214,000 & 360 & 6 & 3 & 8 & 33.5 \\
\hline Average & 82,000 & 109,000 & 250 & 4.2 & 2.2 & 2.8 & 17.5 \\
\hline
\end{tabular}

Note: 12 samples

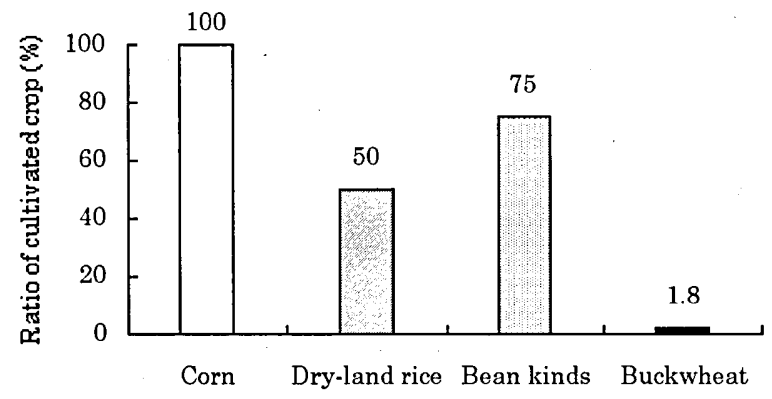

Fig. 4. Main crops.

Family grows cereal crops such as corn, rice, bean and buckwheat (Fig. 4). Especially corns were grown by every family for their own use and for selling. Irrigation water is pumped up by motor engine and delivered to sprinklers nozzles with movable flexible hoses. Ground water levels are ranged from $3 \mathrm{~m}$ to $5 \mathrm{~m}$ as this area is placed between Xiliao river and Jiaolai river, originated from Northern mountains. As for water quality items $\mathrm{pH}$, hardness are 7.8-8.2, $0.2 \mathrm{~g} / \mathrm{l}-0.5 \mathrm{~g} /$, respectively. Though EC was not found in the references, one of the wells shown in Fig. 2, EC was observed as $0.35 \mathrm{mS} / \mathrm{cm}$ in Sept.

\section{PROBLEMS CONFRONTED}

As the results of investigation, following suggestions would be helpful for promoting the pilot villages.

(1) Farmers are suffering the shortages of irrigation water. It would be impossible to dig wells additional by themselves. Financial support by the government is prerequisite to prepare more wells.

(2) Water quality is somehow alkalized. Salt accumulation at crop field is big problems in some area. Before constructing pilot villages, investigation was emphasized on the amount of water. Water qualities were not taken into account.

(3) In some cases, grass fields were strongly damaged because wind shelter forest has no bushes both side of forest band. Ecological consideration should be taken into 
account.

(4) To activate the economic conditions, cultivation machines should be introduced and, appropriate guideline for farm management should be prepared.

It was evaluated that the project for constructing pilot villages was successful. But more detailed care should be promoted to win for the battle against desertification.

\section{ACKNOWLEDGEMENT}

We would like to extend our heartily appreciation to Dr. Kinzou Nagahori, the emeritus professor in Okayama University, Prof. Takao Amaya in Gifu University, Prof. Chaolunbagen in Inner Mongolia Agriculture University, Prof. Liutingxi in Inner Mongolia Agriculture University, Mr. Liufengwu in Inner Mongoria TongLiao City General Department of Water Control and Mr. Tamotsu Funakoshi, the Kyushu university graduate school. This research was implemented by the aid of JSIDRE Fund, Earth Environment Research Grant.

\section{REFERENCES}

Guo, Y., L. Bu and Y. Li 2002 Construction of the pilot village in Horqin sandy land. Academic Field, pp. 15

Hou, F. 2004 A model for developing grass land formation in Horqin sandy land. Pratacultural Science, 21(8): $56-58$

Jiang, D., Z. Liu, Y. Cao, Z. Kou and R. Wang 2002 Desertification and Ecological Restoration of Horqin Sandy Land. China Environmental Science Press (Beijing), pp. 431, 479-480

Zhang, L. 1996 Construction of the wind shelter forest for Horqin sandy land. InnerMongolia Forestry Science \& Technology (Huhhot), (2): pp. 1-4 